\title{
EYE-RELATED PHRASES IN JAPANESE AND UZBEK LANGUAGE
}

\section{Aziza Bakhtiyor Qizi Salokhiddinova}

Trainee Teacher Of The Department Of Japanese Philology, Faculty Of Japanese Studies Tashkent State University Of Oriental Studies

\section{ABSTRACT}

Eyes are organs of the visual system. The human eye is a sense organ that reacts to light and allows vision. It well known that the eye is a sensory organ, and while seeing protects us from external dangers, we perceive the external environment. That is why this part of the body is so important. Sight, whose main function is to help a person feel different things. Thanks to this member, many works of art have created. That is, writers wrote down what they saw with their own eyes.

This article provides an in-depth analysis of the phrases in which these eye functions transferred in Japanese and Uzbek languages.

KEYWORDS: - Eye, eye-related phrases, expressive phrases, eye-catching phrases, combination, distinctive group, external, structural, internal, semantic changes

\section{INTRODUCTION}

According to Ferzana, Meradhi's analysis (2014), there are many expressions related to body parts that express joy, wonder, anger, emotion, coldness, that is, emotions. The muscles of the face make up the largest number of eyes in terms of emotion based on color changes. This is because the structure of the eye attracts a lot of attention.

The same can be said about the situation in the Uzbek language. In both Japanese and Uzbek, we can say that the eye is an organ that expresses the sensations on the face.

It is no coincidence that expressions such as "eyes speak the truth" have not appeared among the people. The words of the heart can be read from the human eye. In the vernacular, it is said, "I see what you mean."
Analysis of eye-related phrases in Japanese and Uzbek

The following is an excerpt from the Japanese and Uzbek eye-related phrases, with eyecatching phrases that correspond to or vice versa in the Japanese phrase.

In the analysis, eye-related phrases are studied based on the following 4 groups.

1. Traditional industry and natural phenomena

2. Expressive phrases

3. Phrases of joy

4. Habits and etiquette

5. Phrases based on eye color

6. Similar structural expressions

In the above grouping, the groups used in the Surenjav Oyunzul and Ferzahna Meradhi study were used. Only eye-based phrases were added by the author as a distinctive group in Japanese 
CURRENT RESEARCH JOURNAL OF PHILOLOGICAL SCIENCES 2(5): 62-68,

May 2021 DOI: https://doi.org/10.37547/philological-crjps-02-05-15

ISSN 2767-3758

(C)2021 Master Journals

\section{Crossref do) 81 Google}

Accepted25 $5^{\text {th }}$ May, 2021 \& Published 31 ${ }^{\text {th }}$ May, 2021

and Uzbek.

The following is an analysis of the above groups by giving examples:

\section{Phrases based on traditional industrial and natural phenomena Japanese phrase:}

「目から鱗が落ちる」(mekara urokoga ochiru) - fish coins spill out of sight

Meaning: to be able to understand something or a situation that you did not understand before.

For example : 先輩に忠告されて目から鱗が落ちたような気 持だった。(Senpaini chyuukokusarete mekara urokoga ochitayouna kimochidatta)

My eyes opened after receiving a warning from Senpai ${ }^{1}$

The 「鱗」 (uroko) (coin) plant in the phrase is a hard round-shaped covering on the outer body of a fish species. It is a metonymic phrase that is used to describe the state of a new appearance when those coins fall, something that has not yet been understood.

Given that the coin never falls out of the human eye, it can be seen as a metaphor for everyday life. Such expressions are a feature of the Japanese language and can be traced back to a traditional industrial practice called the fish industry.

\section{Uzbek phrase:}

\section{Ko'zi ochildi (His eyes opened)}

Meaning: to be able to distinguish good from bad, profit from harm

This phrase in Uzbek is partially consistent with the phrase in Japanese above. There are other expressions in the Uzbek language that are

1 Yaponiyada o'zida katta kursda o'qiydiganlar yoki ishlaydiganlar shunday murohjaat qilinadi. formed from the combination of eye and opening. Only in them there are cases of interjection. The Japanese phrase has only one meaning. Examples of Uzbek phrases are ko'zi ochiq ketmoq (open-eyed), ko'zi moshdek ochilmoq (open-mouthed).

If we pay attention to the phrase " Ko'zi moshdek ochilmoq (to open one's eyes like a mosh)", it can be said to be in the same sense as the Japanese phrase 目から鱗が落ちる. Only in Uzbek was "mosh" used instead of "tanga (coin)". Our Uzbek people make good use of mosh and prepare various meals. It can be assumed that the opening of the mosh during the preparation of food is transliterated and the above expression is formed.

The Japanese, do not use mosh. Ordinary people do not even know how to cook from such frost. Therefore, there is no mistake to say that this phrase is a unique phrase of the Uzbek people. Another peculiarity of this phrase is that it is applied not only to the person but also to the other person.

In addition to the above examples, the Uzbek language also has the phrase "ko'zi ochiq ketmoq", which is widely used in everyday life. Usually, the phrase "ko'zi ochiq ketibdiya bechora" is used when a person dies prematurely. Again, this expression, which stems from the view that a person who has died with open eyes is not yet satisfied with life, also shows the uniqueness of the expressions of our people.

\section{Japanese phrase:}

「目に浮かぶ」(meniukabu) - swam into his eyes

Meaning: a revival of the imagination, as it were.

The phrase <浮かぶ> (ukabu) in the phrase is to maintain balance on the surface, underwater, without sinking in the sky. 
CURRENT RESEARCH JOURNAL OF PHILOLOGICAL SCIENCES 2(5): 62-68,

May 2021 DOI: https://doi.org/10.37547/philological-crjps-02-05-15

ISSN 2767-3758

(C)2021 Master Journals

\section{Crossref do) 81 Google}

Accepted25 $5^{\text {th }}$ May, 2021 \& Published 31 ${ }^{\text {th }}$ May, 2021

There is a perception that various things seem to be floating on the waves, and sometimes there is a state of disappearance, which has become a figment of imagination. That is, the state of being imagined is compared to the state of being invisible to reality.

Japan is an island nation surrounded by the sea, and it is believed that the term was coined because the maritime situation was so close to the people. It could be a phrase invented by the land of the seas or by the Japanese. For example, in landlocked Uzbekistan, there is a phrase that means the same thing.

\section{Uzbek phrase:}

Ko'z o'ngiga kelmoq (To come to mind) -is to see something that is not really visible, to be visible.

The word " o'ngida (right)" in the phrase has the above meaning. That is, the state of the imagination is suddenly expressed in the expression.

\section{Expressive phrases}

Japanese phrase:

目を丸くする (mewo marukusuru) - the eyes become round

Meaning: to open one's eyes wide in astonishment.

For example : 值段の高さに目を丸くする ( nedanno takasani mewo marukusuru)

When he saw that it was expensive, he said he was going to lose his eyesight

目玉が飛び出る (medamaga tobideru) - as if the eyelids were out

Meaning: to open one's eyes in astonishment

Example：目玉が飛び出るほど高い。(Medama ga tobideruhodotakai)

Ko'zi chiqib ketgudek qimmat narxda. (At an exorbitant price).
From the above two examples, it is understood that the meaning of amazement is expressed by making the eye larger than usual. Ferzana, Meradhi (2014) "These expressions are used literally to mean a change in the state of the eye. It is through this particular situation that he expresses a sense of wonder as a result. These examples are considered to be based on metonymy"2.

In Uzbek, as in Japanese, the meaning of a phrase can changed by changing the shape of the eye.

Uzbek phrase:

ko'zi qinidan chiqib keta yozdi

ko'zi xonasidan chiqay dedi

Meaning: 1) anger is reflected in the eyes and dazzles; 2) amazement is reflected in the eyes and dazzles;

This phrase is also skillfully used in the story "Shum bola" by Gafur Gulam, one of the most famous figures of Uzbek literature. As mentioned above, In literary parlance, the phrase "his eyes go out (ko'zlari qinidan chiqib ketmoq)" means "to be very angry."

In the author's work, he expands the meaning of the phrase " ko'zlari qinidan chiqib ketmoq (out of the corner of his eye)" by adding a word or analogy to a component of the phrase, identifying that component, and thus concretizing the meaning of the phrase.

\section{Piece::}

Tepamda latta ko'ylakli, bir qo'li bilan istibro kesagini ushlagan, har bir ko'zi g'ayin-olxo'ridek qinidan chiqib ketgan domlapochcham turar edi ${ }^{3}$.

\footnotetext{
ファルザネモラディ（２００１４４）『身体語彙を含む日本語の慣用句の分析』Hitotsubas hi University Repository

${ }^{3}$ G ‘ulom G`. "Shum bola” Toshkent.1989 49-
} 
CURRENT RESEARCH JOURNAL OF PHILOLOGICAL SCIENCES 2(5): 62-68,

May 2021 DOI: https://doi.org/10.37547/philological-crjps-02-05-15

ISSN 2767-3758

(C)2021 Master Journals

\section{Crossref do) 81 Google}

Accepted25 $5^{\text {th }}$ May, 2021 \& Published 31 ${ }^{\text {th }}$ May, 2021

In general, because phraseologies exist in a ready-made language and are stable, at first glance their structural order does not seem to change. However, in speech, especially in fiction and non-fiction, in poetic texts, phraseology undergoes certain external, that is, structural and internal, that is, semantic changes.

It is clear from the example that in the Uzbek language this phrase serves not only to express surprise, but also anger.

To summarize the above, the eye expresses feelings of wonder and anger by describing the state of arousal. In this respect, the expressions of the two languages are similar. It is possible to conclude that such expressions have arisen, since the movement of the eye is a strange phenomenon that does not occur in everyday life.

\section{Phrases expressing joy}

\section{Phrases in Japanese:}

目が出る (megaderu) - ko'z chiqmoq

Meaning: good luck comes.

Surenjav Oyunzul (2010) explains the idea of luck, the return of happiness, the return of the key to luck as follows:

"If we look at the meaning of the hieroglyph-like phrase「芽が出る」(megaderu), an early bud is interpreted as a sign of happiness and good luck. It is believed that agriculture and nature observations have existed since ancient times, and have evolved from a state of anticipation and great anticipation of an early bud. It has emerged as a meaning that evokes joy through

「目が出る」, a phrase close to the inner state of the Japanese who love to interact with nature. Therefore, it can be concluded that the analogy of a bud was formed as a phrase derived from nature and agriculture".

50betlar
There is no similar phrase in Uzbek. For this reason, the phrase is considered a Japanesespecific phrase.

\section{Habits and phrases based on etiquette}

\section{Phrases in Japanese:}

目を落とす ( mewo otosu) - ko'z tushirmoq

Meaning: 1) to look down; 2) to die.

According to Surenjav Oyunzul's analysis, 「目を落とす」 (mewootosu) is a phrase that refers to the direction of gaze, which includes humility and apology, that is, a reason for not being able to look the other person in the eye.

In other words, it is important for Japanese society to differentiate between human relations between a higher position or a course and a lower position and classmates. Accordingly, there are categories of humility and respect. There are many phrases that are caused by such habits and are reflected in phraseology.

Kagawa (1997) "The Japanese think that not turning a blind eye to an interlocutor can lead to an excuse, to embarrass the interlocutor. When a parent beats a child, the child looks into the parent's eyes and is warned, "Why are you looking like that?" Therefore, in Japan, when a child hears a speech, he looks at the ground ... why do the Japanese avoid the eye so much? One of the reasons for this is that 130 years ago, Japanese society was in a period of "closed politics" before it cut itself off from the world. Looking into the eyes of older people was a major crime at the time, and was sometimes punishable by death. The psychological damage inflicted on the Japanese at that time is still believed to have left its mark."

\section{Phrases in Uzbek language:}

As Kagawa points out, looking at the ground when a child is fighting is a characteristic of Uzbek society. In the Uzbek people, too, it is considered obscene for a child to keep his eyes 
CURRENT RESEARCH JOURNAL OF PHILOLOGICAL SCIENCES 2(5): 62-68,

May 2021 DOI: https://doi.org/10.37547/philological-crjps-02-05-15

ISSN 2767-3758

(C)2021 Master Journals

\section{Crossref do) 81 Google}

Accepted25 $5^{\text {th }}$ May, 2021 \& Published 31 ${ }^{\text {th }}$ May, 2021

on a listener. In this respect, Japanese and Uzbek etiquette are similar. However, there is no such phraseology in Uzbek.

In Uzbek society, eye contact is more commonly used when embarrassed. However, in Japanese society「目を落とす」 means respecting the interlocutor and behaving inferior to the interlocutor by looking down. Not surprisingly, this led to the formation of the phrase.

Not only in Uzbekistan, but in every country, there is an etiquette of respect for one's elders, but it is not reflected in the phraseology. This is also evident in the fact that in today's society, respect and humility are not divided by the style of speech, which is much lighter than in Japan.

\section{Uzbek phrase:}

The Uzbek language has a phraseology with a similar structure.

"Ko'z tashlamoq " has a completely different meaning, although the structure of the phrase is the same as in Japanese. It is simply used to mean to look, to pay attention. Even though the meanings are completely different, and the two languages have the same structure, there are differences in meaning.

\section{Phrases based on eye color}

In Japanese, 白い目で見る (shiroimedemiru) oq ko'zida ko'rmoq (to see in the white eye), 私の目の黒いうち (watashinomenokuroiuchi) ko'zim qoraligida there are phraseologies related to eye color, such as in the dark of the eye. In other nations, too, there are expressions based on eye color. However, despite the fact that the phrase is expressed in the same color, it has different meanings in all nations. For example, the same "qora ko'z (black eye)" is used differently in different countries. There is a similar difference between Uzbek and Japanese.

Phrases in Japanese:
白い目でみる (shirioi medemiru) - oq ko'zida ko'rmoq

Meaning: to look cold, to look with hatred

Looking down angrily, the whites of the eyes widen. White-eyed observation is such an observation that it makes sense to look coldly.

目の黒いうち ( meno kuroiuchi) - ko'zim qoraligida

「目の玉の黒いうち」 (menotamano kuroiuchi) (ko'z qorachig'i qoraliik chog'ida) also has the same meaning, meaning "while alive".

It is said that when a person dies, there are many cases of white eyes remaining, which means "black eyes = alive".

For example :私の目の黒いうちは家への出入りは許さない( Watashino menokuroiuchiva ieheno deirevayurusenai)

I will not allow you to enter the house again while I am alive.

死んでしまって白目をむいてしまわないうち

(Shindashimatte shiromewo muite shimawanaiuchi) That is, it is used in the sense of life.

Also, the example of 「私の目の黒いうちは家への出入りは許さない \lrcorner is the father's prohibition, "As long as I am alive, you will not be invited to the house, nor will you have relations with the family." It is thought to be a term for a black Japanese nation.

\section{Uzbek phrase:}

There are also different expressions in the Uzbek language, such as eye color. For example, the phrase "black eye" was coined in 1468 by Alisher Navoi, the great ancestor of the Uzbek people.

It is also used in his work "Qaro ko'zim (Black Eyes)". Only the phrase "qora ko'z (black eye)" is applied to the beloved. The following is an 
CURRENT RESEARCH JOURNAL OF PHILOLOGICAL SCIENCES 2(5): 62-68,

May 2021 DOI: https://doi.org/10.37547/philological-crjps-02-05-15

ISSN 2767-3758

(C)2021 Master Journals

\section{Crossref do) 81 Google}

Accepted25 $5^{\text {th }}$ May, 2021 \& Published 31 $1^{\text {th }}$ May, 2021

excerpt from the work:

Qaro ko'zum, kelu mardumlug' emdi fan qilg'il,

Ko'zum qarosida mardum kibi vatan qilg'il.

The analysis of Japanese and Uzbek phrases reveals the unique features of each country.

\section{Similar structural expressions}

In Japanese: 目に入れても痛くない (meni iretemo itakunai) - ko'zga solsang ham og'rimaydi

Meaning: caress

In Uzbek: ko'ziga cho'p solmoq

Meaning: to deceive, to distract, to slap in the eye;

In both languages, there is a verb " solmoq (put)" in the phrase, which is similar to the phrase "to put something in the eye", but the meaning of the phrase is opposite. The Japanese phrase "痛くない" (itakunai(painless) makes a difference. Both of these expressions in Japanese and Uzbek are used in Japanese to mean love, while in Uzbek they are used to mean deceit. In both languages, the "eye" is seen as an important organ in the sense of seeing the world, and this is believed to have influenced the phrase.

Regarding the above phrase in Japanese, Surenjav Oyunzul (2010) explains: "Even though the cut is in the negative form, the state of affection is created by the action of “目に入れる”(meniireru). Despite the pain in his eyes, he became positive, expressing love and affection."

Example:

初孫は目に入れても痛くないと言いますね。(h atsumagova meniiretemo itakunaito iimasune)

Direct translation: It said that a grandchild does not hurt even if he seen.

Meaning: Nevara said to be sweeter than fruit.
As can be seen from the above example, the Japanese phrase ““目に入れても痛くない” is used to express love and affection for a grandchild. In Uzbek, too, a grandchild, a son or a daughter considered the sweetest of all, but this love not seen in expressions. However, in Uzbek there is a phrase "ko'zimning oqu-qorasi (black and white of my eyes)", which is applied to a child. This also shows the differences in how emotions expressed in the language of two different cultures.

The aim of this article was to identify the similarities and differences between eye-related expressions in Japanese and Uzbek, and to reveal the differences between the two languages by comparing them with each other.

From the above, it can be concluded that there are many somatic expressions in Japanese that have different meanings. Each phrase has a special significance in the daily life of the people. In the analysis of somatic expressions in Japanese and Uzbek, we have seen similarities and differences between them. For example, the fact that both languages are the means of communication between the Eastern states and have been in economic and cultural contact for centuries explains the semantic similarity and, in some cases, the similarity of the Japanese and Uzbek somatic expressions. However, there are differences due to the mentality, customs and traditions of each nation, which can be assessed by the differences between somatisms in a positive or negative sense. Therefore, the study and in-depth analysis of somatic expressions in Japanese and Uzbek is of great importance to researchers of two languages, past, present, and future. To know a language is to understand a nation, a people, a person, to feel its psyche. In this sense, the study of the relationship between language and culture is important, it is a factor in achieving great results, it opens the door to a wide range of opportunities. 
CURRENT RESEARCH JOURNAL OF PHILOLOGICAL SCIENCES 2(5): 62-68,

May 2021 DOI: https://doi.org/10.37547/philological-crjps-02-05-15

ISSN 2767-3758

(C)2021 Master Journals

crossref dof 80 Google

Accepted25 ${ }^{\text {th }}$ May, 2021 \& Published 31 ${ }^{\text {th }}$ May, 2021

\section{REFERENCES}

1. Madaliyev A. "O'zbek tilining izohli lug'ati” Davlat ilmiy nashriyoti Toshkent, 2006

2. Rahmatillayev Sh. "O'zbek tilining izohli frazeologik lug'ati" Toshkent: 1978 132-151betlar

3. Rahmatullayev Sh. Hozirgi adabiy o'zbek tili. -Toshkent, 2006. 52-bet

4. Tursunov U; Muxtorov J; Rahmatullayev Sh. Hozirgi o'zbek adabiy tili.-Toshkent: O'qituvchi,1992.,101bet.

5. Алпатов В.М. Японская природа и японский язык // История и современность. - М., 2007. - № 2. - С. 219230

6. Быкова С.А. Фразеология японского языка и диалекты // Восточное языкознание. - М., 2003. - С. 60-66

7. Исаев А. Соматические фразеологизмы узбекского языка:Дисс...канд. фил.наук. -T.,1976

8. Surenjav

Oyunzul（2010）『日本語とモンゴル語

の「頭部」の身体語彙慣用句の対照研究

一「目」の身体語彙を中心に一』博士論

文

9. ファルザネモラディ（2014）『身体語彙 を含む日本語の慣用句の分析 : ペルシア 語との 対照を通して 一「目」「手」「口」「身」を用いた表 を中心に一』Hitotsubashi University Repository

10. 三好 準之助

(2010)『「台風の目」と「ojodelhuracán $」$ : 日西比較研究一〈目〉の意義特徵と
の関わりー』博士学位論文

11. 北原保雄（編）（2003）『明鏡国語辞典 第二版』大修館書店

12. 庄司明子（2010）『日英語イディオムの 認知的研究』博士学位論文

13. 有䓢智美（2013）『行為のフレームに基 づく「目」，「耳」，「鼻」の意味拡張 一知覚行為から高次認識行為へー』名古 屋学院大学論集 言語・文化篇

14. 林八龍（2002）『日・韓両国語の慣用的 表現の対照研究』明治書院

15. 浙江財経大学方文武 (2014)『日本語慣用句の成り立ち：理論 的な枠組みと発生のメカニズム』浙江財 経大学

16. http://www.weblio.jp/phrase/

17. http://eyemedia.jp/entertainment/目の色にまつわ る表現いろいろ/

18. http://yuraika.com/shiroimedemiru/ 